\title{
Role Language and Character Language
}

\author{
Satoshi KINSUI \\ Osaka University, Japan \\ kinsui@let.osaka-u.ac.jp
}

\author{
Hiroko YAMAKIDO \\ Fuji Women's University, Japan \\ hyamakid@fujijoshi.ac.jp
}

\begin{abstract}
Since Kinsui's $(2000,2003)$ initial proposal, research on role language has progressed with the topics growing more diverse. In this paper we propose that a peculiar speech style assigned to a certain character in fiction should be treated as character language rather than role language. Role language, which is based on social and cultural stereotypes, is a subset of character language. Given that role language is also a linguistic stereotype, its knowledge should be widely shared by members of the speech community, and its patterns within limits. Character language, on the other hand, allows for various types, being far from being a closed class. We examine and give examples of four types of character language: speech styles that could become actual role language, once shared widely in the speech community; speech styles that are effectively adopted by characters outside of their expected speaker's social and cultural groups; speech styles employed to represent something other than their stereotypes; and uniquely created speech styles.
\end{abstract}

Keywords: role language; character; stereotype; fiction; dialect

\section{Povzetek}

Obseg raziskav, ki se ukvarjajo z jezikom vlog, se je od prvih raziskav (Kinsui 2000; 2003) močno povečal. Tokratna raziskava se posveča govornim slogom $v$ igranih filmih in predlaga, da se specifični govorni slog, dodeljen nekemu značaju v igranem filmu, obravnava kot jezik likov in ne kot jezik vlog. Jezik vlog, ki temelji na socialnih in kulturnih stereotipih, je tako le ena izmed podskupin jezika značaja. Ob predvidevanju, da je jezik vlog jezikoslovni stereotip, je potrebno znanje o njem razširiti med vse člane govorne skupine, med katerimi je takšen jezikoslovni stereotip razširjen. $V$ nasprotju z njim jezik likov dovoljuje različne sloge in ga zato dojemamo kot odprto kategorijo. Članek pregleda in poda primere o štirih različnih tipih slogov jezika likov. Prvi tip je skupina slogov, ki lahko postanejo dejanski jezik vlog, nekoč že razširjen v določeni govorni skupini. Drugi tip je skupina slogov, katere so določeni značaji v igranih filmih uspešno privzeli, vendar se ti razlikujejo od pričakovanih slogov, ki naj bi pripadali govorčevi socialni in kulturni skupini. Tretji tip je skupina slogov, ki zastopajo značilnosti, drugačne od njihovih stereotipov. Zadnja skupina slogov so edinstveno ustvarjeni govorni slogi.

Ključne besede: jezik vlog; lik; stereotip; igrani film; narečje 


\section{Introduction}

The concept of role language ("yakuwarigo") was first introduced by Kinsui (2000). Three years later in 2003, he defined role language as in (1):

(1) Role language ("yakuwarigo"): a set of spoken language features (such as vocabulary, grammar and phonetic characteristics) that can be psychologically associated with a particular character type. (Character's attributes include age, gender, occupation, social status, appearance and personality.)

(Kinsui, 2003, p. 205)

Let us look at the examples in Japanese in (2). While (2a), (2b) and (2c) are all roughly equivalent with the meaning, 'Yes, I know (that),' interestingly each sentence projects a different type of character as its speaker: an elderly man for (2a), a girl for (2b), and a macho guy for $(2 c)$ :

(2) 'Yes, I know (that).'
a. Sō-ja
washi ga yes-COPULA I NOM
shit-teoru-zo.
b. Sō-yo
yes-[ZERO COPULA]-PARTICLE
know-ASPECT-PARTICLE
atashi ga shit-teiru-wa.
I NOM knOw-ASPECT-PARTICLE
c. Sō-da ore ga shit-teru-ze.
yes-COPULA I NOM knOW-ASPECT-PARTICLE

(Teshigawara \& Kinsui, 2011, p. 37 (from Kinsui, 2010, p. 14))

As discussed in Kinsui (2010) and Teshigawara and Kinsui (2011), the different type of character portrayed for each sentence above comes from the combination of the copula (i.e., ja, [ZERO COPULA+] PARTICLE yo, or $d a$ ), first person pronoun (i.e., washi, atashi or ore), aspect form (i.e., teoru, teiru or teru), and final particle (i.e., zo, wa or ze).

Indeed, role language is often used in fiction because it helps the audience immediately understand the character type of the speaker. Kinsui (2003) developed the theoretical framework of role language (that of Japanese in particular) and examined the origin of role language through several case studies. Since this groundbreaking work, research in this area has made great strides, with the publication of various works including two edited volumes of collected papers (Kinsui (ed.), 2007, 2011), a scholarly book (Kinsui, 2014) and a dictionary of role language (Kinsui (ed.), 2014). As research on role language has progressed with the topics growing more diverse, however, there has been a greater need to refine the definition of role language. The following three points in (3), in particular, need further elaboration:

(3) i. The earlier definition does not specify the extent to which knowledge about the association of a particular language feature with a certain character type (or attribute) must be shared for it to be considered a type of role language. Can we consider it to be role language if even only one individual possesses 
the knowledge, or does it have to be shared by all members of the speech community?

ii. The earlier definition does not specify what can constitute a speaker's attributes. Can any attribute of the speaker associated with a particular language feature qualify as role language?

iii. The earlier definition does not specify how role language relates broadly to stereotypes.

Let us begin with (3-i). Though it is impossible for us to determine exactly how many individuals must recognize a certain speech type for it to be considered role language, and though it is also unrealistic to assume that all Japanese speakers share knowledge of any particular role language, it is reasonable to say that the more widely shared such knowledge is, the more likely it is to be established as role language. On the other hand, knowledge that is shared by only a group of fans of a specific work or genre, or by populations of a certain generation, cannot be considered a type of role language.

As for (3-ii), the speaker's attributes linked to role language should only be of easily recognized social and cultural groups (such as gender, generation/age, area of residence/nationality/ethnicity, and social class/occupation). After all, when considered in concrete terms, it is different social and cultural groups who produce regional and social dialectal variations, and we can naturally understand their relation to language. (Sadanobu (2011), in contrast, does not limit role language to any such range of attributes, and rather expands the definition to include any type of language that can be associated with a character; this is close to what we refer to as "character language", as discussed below.) Note that we will extend social and cultural groups to supernatural creatures (e.g., gods, ghosts, monsters, fairies and aliens), artifacts (e.g., robots), and characters of personified animals and inanimate creatures (though they would never speak human language in reality). Kinsui (ed.) (2014) divides varieties of role languages into six categories based on six subgroups of social and cultural groups, (4-i)-(4vi), in The Concise Dictionary of Role Language:

(4) Subgroup Type

i. Gender: male language, female language, gay male language

ii. Age/Generation: elderly male language, elderly female language, middleaged male language, young speaker's language, boy's language, schoolgirl language, gal language

iii. Social class/occupation:

wealthy woman's language, young-lady-from-a-good-family language, boss language, formal-speech language, king/nobles language, powerful person's language, butler's language, army language, comedian's language, doctor's language, (young-)dancing-girl-of-Kyōto language, maid language, yakuza (gangster) language, delinquent-girl's language, sumo-wrestler language 
iv. Region/nationality/ethnicity:

Osaka language/Kansai language, rural language, Okinawan language, Owari language, Tosa language, Nagoya language, Kyūshū language, Kyōto language, arimasu-language, aruyolanguage, pidgin, broken language, Chinese language

v. Pre-modern: Edo language, princess language, Kyōto-Ōsaka language, court-noble language, live-in student language, merchantclass language, ninja language, samurai language, prostitute language, jii (old chaperon) language, downtown language

vi. Imaginary creatures: alien language, god language, ghost language

Finally consider (3-iii). Characters in fiction who are assigned role language to speak often exhibit other stereotypes associated with the role language. For example, a speaker who speaks a rural language is not only a rural person (= the primary stereotype), but is also portrayed as having other stereotypical attributes of a person from the country: unsophisticated, uneducated and gullible. A character who speaks a rural role language but does not behave like a "rural person" does not represent a typical example of how that role language is used.

Now that we limit the speaker's attributes of role language to social and cultural groups, it becomes apparent that this definition excludes some fictional characters who speak in a somewhat peculiar manner that is neither role language nor the standard language. Up to now, in the short history of role language research, which is only about fifteen years long, the speech of such characters has sometimes been considered as a form of role language. In this paper, however, we will consider this style of speech "character language", not role language. There are four representative types of character language, as in (5):

(5) i. a speech style that, while associated with a particular social or cultural group, is not widely enough recognized within the speech community at large to qualify as true role language

ii. a speech style in which a type of role language is unexpectedly adopted by a character who does not belong to the social or cultural group with which it is typically associated

iii. a speech style in which a type of role language is employed to express its speaker's personality, rather than the stereotype of the social or cultural group with which it is associated

iv. a peculiar speech style that does not correspond to any social or cultural group, but is assigned to a certain character for his/her role in the story

In the following chapters, we will examine each type of character language with examples. 


\section{Character Language Type (i): Restricted Role Language}

Nishida (2011) and Togashi (2011) discuss a particular type of speech by young women with a certain attribute called tsundere, who appear in works targeting comicbook or anime fanatics. The term tsundere can refer to either (i) a state of mind in which a young woman behaves with excessive coldness toward a guy even though she is actually crazy about him underneath, or (ii) a young woman with this state of mind. The particular speech style observed in tsundere women involves stuttering and a frequent use of imperative and strong conclusive expressions. Young female individuals can be considered as a social and cultural group; however, the knowledge of tsundere in connection with this particular speech style is shared only among comic-book or anime fanatics, not more widely in the Japanese speech community. The tsundere speech style discussed in Nishida (2011) and Togashi (2011) is therefore a perfect example of character language, rather than true role language.

Another example of such restricted role language is aruyo language, a particular speech style often associated with Chinese people. Kinsui (2014) explores how aruyo language, a kind of pidgin, has come to serve as a type of role language historically. There are two kinds of constructions with distinctive endings: (i) the aru construction, used for affirmation, which is formed by adding the common Japanese existential verb aru to the base form of a verb or a noun, and (ii) the yoroshii construction, used for commands, requests and suggestions, which is formed by adding yoroshii (lit. 'good') to the base form of a verb. (6) is an extract from Yama-otoko no Shigatsu [The Mountain Man in April] (included in Chümon no Ōi Ryōri-ten [The Restaurant of Many Orders] (1921)) by Kenji Miyazawa. As far as we know, this is the earliest example of aruyo language observed in fiction:

(6)「あなた、この薬のむよろしい。毒ない。決して毒ない。のむよろしい。 わたしさきのむ。心配ない。わたしビールのむ、お茶のむ。毒のまない。 これながいきの薬ある。のむよろしい。」

（意訳）あなたはこの薬を飲みなさい。これは毒ではない。決して毒では ない。飲みなさい。私が先に飲むから心配しなくていい。私はビ一ルを飲 み、お茶を飲むが、毒は飲まない。これは長生きの薬である。飲みなさ い。

（宮沢賢治(1921)「山男の四月」)

Anata kono kusuri nomu yoroshii. Doku nai. you this medicine drink good poison not.exist

$\begin{array}{llllll}\text { Kesshite doku nai. } & \text { Nomu yoroshii. Watashi saki nomu. } \\ \text { never poison not.exist } & \text { drink good I } & \text { first drink } \\ \text { Shinpai nai. } & \text { Watashi biru nomu, ocha nomu. } & \\ \text { worry not.exist I } & \text { beer drink tea drink } & \end{array}$

Doku noma-nai. Kore nagaiki-no kusuri aru. Nomu yoroshii. poison drink-not. this longevity-GEN medicine exist. drink good 
'Take this medicine. It's not poison. This is by no means poison. Take it. I will go first, so no worries. I drink beer. I drink tea. But I don't take poison. This is a medicine for a long life. Take it.'

-Kenji Miyazawa (1921) Yama-otoko no Shigatsu

Here in (6) a typical use of aruyo language can be observed, with both the aru and yoroshii constructions included. Interestingly, however, this work is unique among works of the time in using aruyo language to represent Chinese people. For example, in Kuchimane (1923) by Kyūsaku Yumeno, a work from the same era with a theme similar to that of The Mountain Man in April, aruyo language cannot be observed at all. Furthermore, more common in other works of popular culture was the arimasu construction from the Meiji Era, derived from aru + masu (polite marker). Aruyo language has become common only since it started appearing in certain influential works such as the manga series Norakuro (the late 1930s-). The speech style used in Miyazawa's work was indeed ahead of its time, for aruyo language had not yet become established as a role language of Chinese characters. Kenji Miyazawa adopted aruyo language in his work probably because he found its effect interesting, not because he foresaw that this particular speech style would be associated with Chinese people (that is, understood to be the role language of Chinese people). Besides, it is unlikely that Miyazawa was influential enough during his lifetime to start this social trend, so we cannot find any strong relation of this children's story by Miyazawa to the fact that aruyo language later became popular and established as role language.

\section{Character Language Type (ii): Role Language Shifted Outside of Its Social or Cultural Groups}

In Disney's animated films, there are quite a few characters who speak African American Vernacular English (AAVE) though they are not African American. AAVE is "a cover term describing distinctive varieties of English spoken by Americans of African descent" (O'Grady et al., 2005, p. 628), with distinctive linguistic features in phonology, morpho-syntax and lexicon. (See Green (2002) for the details.) Given that it is typically associated with a particular ethnicity (i.e., Americans of African descent), AAVE is no doubt a type of role language.

Lippi-Green $(1997,2012)$ reports an interesting study of varieties of English used in Disney's animated films from 1937 to 1994. Her findings include the following:

(7) i. Among a total of 371 characters, whereas 43.1 percent $(n=161)$ speak SAE (Standard American English) (and the like), 13.9 percent speak other varieties of US English ( $8 \%$ regionally peripheral and $5 \%$ socially peripheral).

ii. Among a total of 161 SAE speakers, 43.1 percent appear in humanoid form, and 54.4 percent in animal form. 
iii. All AAVE-speaking characters appear in animal rather than humanoid form (although Lippi-Green carefully notes that "[g]iven the low overall number of AAVE speakers, [...], it is hard to draw any inferences from that fact").

(Lippi-Green, 2012, p. 115, p. 123)

It is not surprising that in these films for children many of the characters are (personified) animals, but the question is: among these animal characters, who would never speak human language in reality, how does Disney decide which ones speak SAE and which ones speak AAVE? Since AAVE is typically associated with African Americans, it might be reasonable to assume that animal characters of African descent would speak AAVE; however, it seems that things are not so simple. In The Lion King (1994), for example, whose characters are all African animals, one of the minor characters, the hyena Shenzi, does speak AAVE, but the main character, the lion Simba, as well as his father and best friend all speak SAE (or something close to it) (Lippi-Green, 2012, p. 122). In fact, the interesting study conducted by Dobrow and Gidney (1998) shows that many children's animated TV programs use "dialect stereotypes to indicate a character's personality or status as a hero or villain or as serious or comic" (p. 115), and "[d]ialects are frequently used by minor characters, both comic and evil" (p. 116). If this also applies to Disney's animated films, then those AAVE-speaking animal characters should either have comic personalities or be villains. Is this really the case here?

As our sample we have selected five animal characters who speak AAVE in Disney's animated films. ${ }^{1}$ Information on each character, including his or her behavioral evaluation (positive, negative or mixed) and appearance, is given in Table 1 (partially taken from Lippi-Green (2012, pp. 120-1)).

Table 1: Five animal characters who speak AAVE in Disney's animated films

\begin{tabular}{|l|c|c|c|c|c|}
\hline $\begin{array}{l}\text { Film } \\
\text { (release year) }\end{array}$ & Story setting & Character name & Sex & $\begin{array}{c}\text { Behavior } \\
\text { evaluation }\end{array}$ & Appearance \\
\hline \hline Dumbo (1941) & Florida, US & Jim Crow, crow & $\mathrm{M}$ & mixed & black; stylish \\
\hline $\begin{array}{l}\text { The Jungle } \\
\text { Book (1967) }\end{array}$ & India & $\begin{array}{c}\text { King Louie, } \\
\text { orangutan }\end{array}$ & $\mathrm{M}$ & mixed & red; tall, fat \\
\hline $\begin{array}{l}\text { The Lion King } \\
\text { (1994) }\end{array}$ & Africa & Shenzi, hyena & $\mathrm{F}$ & negative & dark grey \\
\hline $\begin{array}{l}\text { Mulan (1998) } \\
\text { Ancient } \\
\text { China }\end{array}$ & Mushu, dragon & $\mathrm{M}$ & positive & red; tiny \\
\hline $\begin{array}{l}\text { The Princess } \\
\text { and the Frog } \\
\text { (2009) }\end{array}$ & $\begin{array}{c}\text { New Orleans, } \\
\text { US }\end{array}$ & Louis, alligator & $\mathrm{M}$ & positive & $\begin{array}{c}\text { olive green; } \\
\text { tall, fat }\end{array}$ \\
\hline \hline
\end{tabular}

\footnotetext{
${ }^{1}$ Many of the descriptions for each character given later in this chapter are taken from The Disney Wiki [http://disney.wikia.com/wiki/The_Disney_Wiki].
} 
Let's start with Jim Crow in Dumbo. He is the leader of a flock of five crows who speak and sing in AAVE. The name Jim Crow has strong racial connotations, and the scene where the crows sing the song titled "When I See an Elephant Fly" reminds many viewers of a "Blackface" minstrel performance. At the same time, his character is portrayed as "generally good-natured, albeit with tendencies towards jokes and teasing" (The Disney Wiki). He is also very fashionable, with a blue vest, a brown bowler hat with a blue feather accessory, pink spats, and a cigar). His role provides an example of a kind of African American stereotype: Zip Coon, a famous Blackface characters characterized as "an arrogant, ostentatious figure, [...] dressed in high style and spoke in a series of malaprops and puns that undermined his attempts to appear dignified, [...]" (Black-Face.com). (See Bogle (2001) and Luther, Lepre and Clark (2012) (among others) for the detailed discussions of African American stereotypes in U.S. media.)

The second character to be examined is the orangutan King Louie in The Jungle Book. He scats and speaks in AAVE, and "provides an example of another kind of stereotype: the African American entertainer, the jokester or trickster" (Lippi-Green, 2012, p. 123). In the story, his only goal in life is "to be the one thing he is not: a human being, a man" for, as Lippi-Green explains, "African American males who are not linguistically assimilated to the sociolinguistic norms of a middle and colorless United States are allowed very few possibilities in life, but they are allowed to want those things they do not have and cannot be" (p. 123).

King Louie reminds us of another AAVE-speaking character, the alligator Louis in The Princess and the Frog, which was released forty-two years after The Jungle Book. He loves playing the trumpet, and "his dream is to become a famous jazz singer who can perform in front of a human audience without scaring anyone," and "his last attempt to play with humans ended with his audience panicking at the sight of an alligator" (The Disney Wiki). He is, however, different from King Louie in The Jungle Book in that his dream comes true in the end, and in the way he provides comic relief in the story; despite his huge body and scary appearance, he has several phobias and acts silly sometimes. This side of his personality and behavior fits another stereotype of African American, the Tom, who is kind-hearted and submissive. ${ }^{2}$

The next AAVE-speaking animal character to be examined is Mushu, a mythical dragon, in Mulan (voiced by Eddie Murphy). His role is to provide comic relief in the story. Despite his small-sized body and silly nature, he plays the role of guardian to the heroine Mulan. Indeed, he is able to help her escape from the biggest crisis by blowing fire. He represents another African American stereotypes: the buddy or sidekick.

\footnotetext{
${ }^{2}$ The Princess and the Frog is set in New Orleans, US, where some of the human characters including the heroine Tiana, a young African-American girl, speak AAVE. So it is reasonable that Louis speaks AAVE, too (though another important animal character, the firefly Ray, speaks Cajun) (Lippi-Green, 2012, p. 121).
} 
Our last AAVE-speaking character is the hyena Shenzi in The Lion King (voiced by Whoopi Goldberg). As mentioned above, although the story is set in Africa, some of the animal characters exhibiting positive behavior (including the main character Simba and his father Mufasa, who is the King of the Pride Lands) speak SAE or slight variations thereof. On the other hand, AAVE-speaking Shenzi, whose behavior is evaluated as negative, is the leader of the hyena trio, who are "loyal followers and minions" of Mufasa's evil brother, Scar (The Disney Wiki). As Lippi-Green (2012) points out, Shenzi's use of this specific type of dialect would send a "familiar" message to viewers including children: "AAVE speakers occupy the dark and frightening places, where Simba does not belong and should not be; he belongs on the sunny savannah where *SAE speakers like his father live" (p. 122).

Thus, a speech style can sometimes be employed by a character who is not a member of its associated social or cultural group. We have examined the application of AAVE to animal characters in Disney's animated films. Although they all represent good examples of African American stereotypes, they are not African American, so the AAVE employed by them should be considered character language rather than role language.

\section{Character Language Type (iii): Regional Dialect Employed to Represent a Character's Personality}

When a regional dialect is used as role language in fiction, it typically means that its story is set in that region, or that the speaker of the dialect exhibits some stereotype associated with the region. It is also usually the case that lines in dialect are assigned to minor characters. The main character and other important characters, on the other hand, generally speak a standard language. Though from the region where the dialect is spoken, they typically do not speak with a strong accent or speak a language close to the standard one. This is because it is easier for the audience to understand the lines and to identify themselves with the main character. (This is called the theory of role language (Kinsui, 2003; Kinsui, Tanaka \& Okamuro (eds.), 2014).)

In some TV dramas featuring a Japanese regional dialect, their main characters speak the dialect with a strong accent from beginning to end, however. For example, the heroine of Yae no Sakura (2013), Yae, born to a gunnery master in Aizu, Fukushima, in the last days of the Tokugawa shogunate, grew up speaking Aizu dialect with a thick accent. She continued to speak this dialect, however, even after she had grown up and moved to Kyoto. Her use of the dialect can be interpreted as the creators' way of symbolically showing that throughout her life, the heroine held on to the strong spirit that she had acquired in her youth. Thus, a regional dialect can be

\footnotetext{
${ }^{3}$ It is interesting to note that Scar, who is serious and a villain, speaks British English. This matches Dobrow and Gidney's (1998) finding: dialects and foreign accents are frequently employed by a comic and a villain in children's animated TV programs though "none of the comic characters in [their] sample used British English" (p. 116).
} 
used to show a character's personality, and here it should be considered as character language, not as role language (Kinsui, Tanaka \& Okamuro (eds.), 2014).

\section{Character Language Type (iv): Unique Character Language}

In Haruki Murakami's Umibe no Kafuka [Kafka on the Shore] and 1Q84, there are two characters whose speech styles have a big impact on readers: Mr. Nakata and FukaEri respectively. In Kafka on the Shore Mr. Nakata is an aged resident of Nakano Ward, Tokyo, who is mentally retarded and illiterate, but has a special ability to speak to cats. His shadow on the ground is only half as dark as ordinary people's, and he lacks all sorts of desires including sexual desire. At the beginning of the story, he lives on a subsidy while making some extra money by occasionally searching for lost cats. Later, having committed murder, though it is not clear to the reader if it really happened or not, he leaves home, and starts on an adventurous journey. He calls himself by his own family name, Nakata, and speaks extremely politely to anybody including cats with the sentence-ending -de arimasu. The example in (8) is a dialogue between Mr. Nakata and Mr. Ōtsuka (a cat living in the neighborhood):

(8)「しかし、あんたは人間にしても、いささか変わったしゃべり方をする ね」とオオツカさんは言った。

「はい、みなさんにそう言われます。しかしナカタはこういうしゃべり 方しかできないのです。普通にしゃべりますと、こうなります。頭が悪 いからです。昔から頭が悪かったわけではないのですが、小さいころに 事故にあいまして、それから頭が悪くなったのです。字だってかけませ ん。本も新聞も読めません」

（村上春樹(2002)『海辺のカフカ(上)』文庫版, p. 96）

"I must say, though, that for a human you have an odd way of talking," Otsuka commented.

"Yes, everybody tells me that. But this is the only way Nakata can speak. I try to talk normally, but this is what happens. Nakata's not very bright, you see. I wasn't always this way, but when I was little I was in an accident and I've been dumb ever since. Nakata can't write. Or read a book or a newspaper."

-Haruki Murakami (2005) Kafka on the Shore (P. Gabriel, Trans.) Knopf, p. 44

Kato (2009) points out that Mr. Nakata's speech style was greatly influenced by that of Eeyore in Atarashi Hito yo Mezame yo [Rouse Up O Young Men of the New Age!] (1983) by Kenzaburō Ōe, who modelled Eeyore after Hikaru, his own brain-damaged son (p. 268).

In 1Q84, Fuka-Eri (Eriko Fukada) is a seventeen-year-old girl who contributed a novel titled Küki Sanagi [Air Chrysalis] to a publisher, which led her to meet the main character, Tengo, a prep school teacher and would-be novelist. Though suffering from dyslexia, Fuka-Eri has an extraordinarily good memory and a talent for music, probably showing the characteristics of savant syndrome. She speaks extremely 
monotonously without any intonation, and does not use polite language at all. She does not use any address terms, response markers or final particles. Nor does she use a rising intonation for question sentences, a fact indicated by Murakami by his omission of a question mark, so it is sometimes difficult for the audience to tell if they are declarative or interrogative in the original Japanese text.

(9)「あってもらいたいひとがいる」とふかえりは言った。

「僕がその人に会う」と天吾は言った。

ふかえりは肯いた。

「どんな人?」と天吾は質問した。

質問は無視された。「そのひととはなしをする」と少女は言った。

「ニチヨウのあさはあいている」と疑問符のない質問を彼女はした。

「あいている」と天吾は答えた。まるで手旗信号で話をしているみたいだ

、と天吾は思った。（村上春樹(2009)『1Q84(Book 1)』p.98）

"There's someone to meet," Fuka-Eri said.

"Someone you want me to meet?"

She nodded.

"Now, who could that be?"

She ignored his question. "To talk to," she added.

"Are you free Sunday morning," she asked, without a question mark.

"I am," Tengo said. It's as if we're talking in semaphore, he thought.

-Haruki Murakami (2012) 1Q84 (J. Rubin, Trans.) DIP Inc. Vintage, p. 69

Mr. Nakata and Fuka-Eri are both mentally retarded, the result of childhood traumaMr. Nakata having been physically abused by his teacher in elementary school, and Fuka-Eri having been sexually abused by her own father. On the other hand, both of them are endowed with a power to receive messages from the supernatural realm, beyond what ordinary people would ever know, and it is these messages that guide their actions throughout the stories and therefore move the whole stories forward. Their peculiar speech styles help the audience understand that they are mentally retarded and furthermore connect the main character as well as other characters with the supernatural. In this sense, their language faculties and practical use of language are very important attributes in developing the stories, but these attributes cannot be analyzed as the application of any stereotype. Therefore, we cannot consider their speech styles as role language.

\section{Summary}

In this paper we have proposed that a peculiar speech style assigned to a certain character in fiction should be treated as character language rather than role language. Role language, which is based on social and cultural stereotypes, is a subset of character language. Given that role language is also a linguistic stereotype, its knowledge should be widely shared by members of the speech community, and its patterns within limits. Character language, on the other hand, allows for various 
types, being far from being a closed class. We have examined and given examples of four types of character language: speech styles that could become actual role language, once shared widely in the speech community; speech styles that are effectively adopted by characters outside of their expected speaker's social and cultural groups; speech styles employed to represent something other than their stereotypes; and uniquely created speech styles.

\section{Acknowledgements}

We thank Dane Hampton and Charles Mueller for proofreading the manuscript.

\section{References}

Black-Face.com. (n.d.) Blackface! Retrieved October 19, 2015, from http://black-face.com

Bogle, D. (2001) Toms, Coons, Mulattoes, Mammies, \& Bucks, fourth edition. New York: Continuum.

Dobrow, J. and Gidney, C. (1998) "The good, the bad, and the foreign: The use of dialect in children's animated television." ANNALS, AAPSS 557: 105-119.

Green, L. J. (2002) African American English: A Linguistic Introduction. Cambridge: Cambridge University Press.

Kato, T. (2009) Murakami Haruki Yellow Pages 3. Tokyo: Gentosha.

Kinsui, S. (2000) "Yakuwarigo tankyū no teian [A proposal for exploring role language." In K. Sato (ed.) Kokugo Ronkyū [Inquiries into Japanese Language] vol. 8, Kokugo-shi no Shin-shiten [A New Perspective on the History of the Japanese Language]. Tokyo: Meiji Shoin, pp. 311-35.

Kinsui, S. (2003) Virtual Nihongo: Yakuwarigo no Nazo [Virtual Japanese: The Enigma of Role Language]. Tokyo: Iwanami Publisher.

Kinsui, S. (ed.) (2007) Yakuwarigo Kenkyū no Chihei [New Horizon of Role Language Research]. Tokyo: Kurosio Publisher.

Kinsui, S. (2010) "On 'role language' in contemporary Japanese: An investigation of stereotypical styles in Japanese language." Proceedings of the Symposium 'Yakuwari/Kyarakutā/Gengo' [Roles/Characters/Languages], March 28-29, 2009, Kobe University, Japan, pp. 51-54.

Kinsui, S. (ed.) (2011) Yakuwarigo Kenkyū no Tenkai [Development of Role Language Research]. Tokyo: Kurosio Publisher.

Kinsui, S. (2014) Kore mo Nihongo Aruka?: Ijin no Kotoba ga Umareru Toki [Is This Also Japanese?: When Aliens' Language Was Born]. Tokyo: Iwanami Publisher.

Kinsui, S. (ed.) (2014) Yakuwarigo Shōjiten [The Concise Dictionary of Role Language]. Tokyo: Kenkyusha. 
Kinsui, S., Tanaka, Y., and Okamuro, M. (eds.) (2014) Dorama to Hōgen no Atarashii Kankei: "Kānēshon" kara "Yae no Sakura", Soshite "Ama-chan" e [A New Relationship between Dramas and Dialects: From "Carnation" to "Yae no Sakura", and "Amachan"]. Tokyo: Kasama Shoin.

Lippi-Green, R. (1997) English with an Accent: Language, Ideology, and Discrimination in the United States. London: Routledge.

Lippi-Green, R. (2012) English with an Accent: Language, Ideology, and Discrimination in the United States, second edition. Oxon: Routledge.

Luther, C. A., Lepre, C. R. and Clark, N. (2012) Diversity in U.S. Mass Media. Malden: Willey-Blackwell.

Nishida, T. (2011) "Yakuwarigo toshiteno tsundere hyōgen: 'Jōyōsei' no umu ni chakumoku shite [Tsundere expressions as role language, focusing on circumstances of usage]." In: Kinsui, S. (ed.), pp. 265-78.

O'Grady, W., Archbold, J., Aronoff, M., and Rees-Miller, J. (2005) Contemporary Linguistics: An Introduction, fifth edition. Boston: Bedford/St. Martin's.

Sadanobu, T. (2011) "Kyarakuta wa bumpō o doko made kaeru noka? [How much does Modern Standard Japanese grammar vary in accordance with the speaker's "character"?]." In: Kinsui, S. (ed.), pp. 17-26.

Teshigawara, M. and Kinsui, S. (2011) "Modern Japanese 'role language' (yakuwarigo): Fictional orality in Japanese literature and popular culture. Sociolinguistic Studies 5(1): 37-58.

Togashi, J. (2011) "Tsundere zokusei niokeru gengo-hyōgen no tokuchō: Tsundere hyōgen kēsu sutadī [Properties of the tsundere character and their relationship to linguistic expression: A case study of tsundere expressions]." In: Kinsui, S. (ed.), pp. 279-95. 
